\section{Produžen QTc interval izazvan amitriptilinom}

\begin{abstract}
APSTRAKT
Prikazan je slučaj 65-godišnje bolesnice kod koje je ustanovljena povezanost primjene amitriptilina i pojave palpitacije i prolongacije QT intervala, četiri mjeseca od početka terapije. Elektrokardiogram je pokazao produženje QTc od 505 milisekundi (ms). Amitriptilin je primjenjen radi liječenja umjerene depresivne epizode, istovremeno sa dugotrajnom primjenom enalapirla u liječenju hipertenzije. Nakon prekida primjene amitriptilina došlo je do povlačenja simptoma i normalizacije QTc na 420 ms.
\end{abstract}

\section{KLJUČNE RIJEČI}

produženje QT intervala, amitriptilin, palpitacije, vrtoglavica

DOI: $10.7251 / S M D 1201036 M$

(Scr Med 2012;43:36-7)

\section{Danijela Mandić, Lana Nežić}

\author{
${ }^{1}$ Klinika za unutrašnje bolesti, \\ Univerzitetski-klinički centar Banja \\ Luka, 78000 Banja Luka, \\ ${ }^{2} Z a v o d$ za farmakologiju, \\ toksikologiju i kliničku \\ farmakologiju, Medicinski fakultet \\ Univerzitet u Banjaluci \\ 7800 o Banja Luka, Republika \\ Srpska, Bosna i Hercegovina
}

Korespodencija Dr Danijela Mandić Univerztetski-klinički centar Banja Luka 12 beba, 78000 Banja Luka Republika Srpska Bosna i Hercegovina Telefon: +38765305341 email: danijela4273@yahoo.com

Submitted: January 15, 2012 Accepted: May 14, 2012
Bolesnica stara 65 godina je upućena na internistički pregled zbog iznenadne pojave palpitacija i vrtoglavice bez gubitka svijesti. Taj se poremećaj javlja u toku uobičajene fizičke aktivnosti ili emocionalnog stresa, a pojavio se od prije tri mjeseca. Kliničkim pregledom je ustanovljeno dobro opšte stanje; arterijski krvni pritisak 140/70 mmHg, puls 69/min, uredan auskultatorni nalaz srca i pluća, trbušni zid mekan i bezbolan, bez kongestije vena vrata $\mathrm{i}$ edema donjih ekstremiteta. Laboratorijske analize su pokazale da su osnovni hematološki i biohemijski parametri u referentnim vrijednostima. Na elektrokardiogramu uočen je sinusni ritam sa frekvencijom 63 otkucaja/min i PQ o.20”. QT interval (QTi) bio je produžen, 480 milisekundi (ms). Korigovani QTi (QTc) iznosio je $505 \mathrm{~ms}$. Zbog arterijske hipertenzije, bolesnica više godina uzima enalapril, 20 mg/dan, a zbog umjerenih depresivnih epizoda, četiri mjeseca, uzima amitriptilin, $50 \mathrm{mg} / \mathrm{dan}$. Zbog sumnje da je amitriptilin uzrok produženog QT intervala, lijek je postepeno isključen bez uvođenja drugog antidepresivnog lijeka. $\mathrm{Na}$ kontrolnom pregledu, četiri sedmice kasnije, bolesnica je negirala pojavu palpitacija i vrtoglavice, uz perzistenciju depresivnog raspoloženja; na EKG je registrovan sinusni ritam, frekvencija srčanog rada iznosila je 75 otkucaja/ min, normalan QT interval (370 ms) i QTc (420 ms).

\section{Diskusija}

U prikazanom slučaju je opisan klinički značajan produžetak QTe intervala koji je najvjerovatnije izazvan amitriptilinom. Za sigurnu uzročno-posljedičnu vezu između a mitriptilina i prolongiranog QTc intervala trebalo bi da se ustanovi da li bi ponovno davanje amitriptilina dovelo do pojave prolongiranog QTc intervala, ali to bi u ovom slučaju za bolesnika mogao biti izvor nepotrebne opasnosti. Činjenica da je nakon prestanka unošenja lijeka došlo do korekcije QTc intervala, nestanka palpitacija i pratećeg vertiga. Te promjene dodatno ukazuju na uzročno posledičnu vezu lijeka i neželjenih kliničkih simptoma.

QT interval je vrijeme od početka QRS kompleksa do kraja T zubca na elektrokardiogramu. To je vrijeme od početka depolarizacije do kraja repolarizacije miokarda. Dužina QTi varira uslijed brzine otkucaja srca. Zato se QTi može korigovati u odnosu na brzinu srčanog rada pomoću $R R$ intervala (tj. vremena između dva uzastopna $R$ zubca) pomoću slijedeće formule:

\section{$\mathrm{QTc}=\mathrm{QTi} \bullet \sqrt{\mathrm{RR}}$}

Smatra se da normalna maksimalna dužina QTc intervala iznosi $430 \mathrm{~ms}$ kod muškaraca, $450 \mathrm{~ms}$ kod žena, a 440 
ms kod djece. ${ }^{2}$ Produžen QTc interval je uroden ili stečen. Urođen je posljedica mutacije gena koji kodiraju voltažnosenzitivne $\mathrm{Na}^{+} \mathrm{i} \mathrm{K}^{+}$kanale. Međutim, 32\% asimptomatskih nosioca mutacije ima normalan QTc, dok 25-30\% osoba sa produženim nema genetski postavljenu dijagnozu. ${ }^{3.4}$ Lijekovi su najčešći uzrok stečenog dugog QTc intervala.

Produžen QTc interval je znak prolongirane repolarizacije miokarda komora što vodi nastanku polimorfne ventrikularne tahikardije (tipa re-entry) poznate pod nazivom torsade de pointes. Pri tome, abnormalni ritam (200/250) obično spontano prestane, ali ponekad dolazi do ventrikularne tahikardije ili ventrikularne fibrilacije, ${ }^{4}$ stanja koja je praćeno palpitacijama, vrtoglavicom, sinkopom, a nekad i smrtnim ishodom.

Najčešce dug QTc izazivaju antiaritmijski lekovi (klasa I-prokainamid, hinidin i klasa III-amiodaron, sotalol), a zatim atidepresivi (amitriptilin, imipramin, doksepin), antibiotici (azitromicin, klaritromicin, eritromicin, metronidazol + alkohol), antifungalni lijekovi i antipsihotici..$^{2,3,5}$ Sok grejpfruta povećava rizik za nastanak prolongiranog QTc intrevala izavan amiodaronom jer inhibira metabolizam tog leka. ${ }^{2}$

Subkliničke genetske mutacije su vjerovatno glavni razlog što su neke osobe osjetljivije od ostalih na lijekove koji prolongiraju QTc interval. Zato se kod odsustva genetske dijagnostike, ${ }^{6} \mathrm{u}$ prevenciji nastanka produženja QTe intervala, savjetuje slijedeće: EKG monitoring prije i poslije uvođenja terapije rizičnim lijekovima, provjera porodične anamneze o slučajevima eventualne iznenadne smrti rodaka u mladem životnom dobu i pojave sinkope ili aresta srea kod samog bolesnika. Posebnu pažnju pri propisivanju rizičnih lijekova, uključujući amitriptilin, treba obratiti i na opšte faktore rizika za nastanak produženog QTc intervala (ženski pol, hipokalijemija, hipomagnezijemija, bradikardija, srčana insuficijencija i štetne kombinacije lijekova). ${ }^{6}$
Možemo zaključiti da pri propisivanju bilo kog lijeka za koji se zna da nekada produžava QTc interval iznad normalnih granica, treba procjeniti odnos koristi od primjene lijeka i mogućnosti relativno rijetkog rizika koji nekad i život ugrožava. Dilema je postojala između suzbijanja lake depresije i očigledne pojave aritmije srca i vroglavice kod našeg bolesnika. Odlučli smo da je veći rizik od davanja amitriptilina nego od lake depresije. Zato smo privremeno obustavili primjenu ovog lijeka. Ostaje da se ustanovi da li bi titriranjem lijeka na manju dozu ili uvodenjem nekog drugog antidepresivnog lijeka postigli adekvatan terapijski odgovor koji u isto vrijeme ne bi ispoljavao nepovoljno i potencijalno opasno dejstvo na funkciju srca.

\section{Doprinos autora \\ DM je vodila brigu o bolesniku. U svemu ostalom, doprinos oba autora je podjednak.}

\section{Sukob interesa}

Autori su izjavili da ne postoji potencijalni sukob interesa.

\section{Reference}

1. Gupta A, Lawrence AT, Krishnan K, Kavinsky CJ, Trohman RG. Current concepts in the mechanisms and management of druginduced QT prolongation and torsade de pointes. Am Heart $\mathrm{J}$ 2007;153: 891-9.

2. Jayasngher R, Kovoor P. Drugs and the QTe interval. Aust Prescr 2002;25:63-5.

3. Yap YG, Camm AJ. Drug induced QT prolongation and Torsades de Pointes. Heart 2003;89:1363-72.

4. Priori SG. Inherited arrhythmogenic diseases: the complexity beyond monogenic disorders. Circ Res 2004; 94:140-5.

5. Allen LaPointe NM, Curtis LH, Chan KA, et al. Frequency of high-risk use of QT-prolonging medications. Pharmacoepidemiol Drug Saf. 2006;15:361-8

6. Savić N, Gojković-Bukarica LJ. Produženi QT interval: genetska osnova i uticaj lekova. Vojnosanit Pregl 2008;65:308-12.

\title{
QTc Prolongation Caused by Amitriptyline
}

\section{Danijela Mandić, Lana Nežić}

\begin{abstract}
We report a 65-year-old female patient who developed amitriptyline-associated palpitations, dizziness and prolonged QTC interval, four months after therapy had started. The electrocardiogram demonstrated prolonged QTc interval of 505 ms. After cessation of amitriptyline all symptoms reversed and QTc interval normalized to $420 \mathrm{~ms}$.
\end{abstract}

\section{KEY WORDS}

QT prolongation, amitriptyline, palpitations, dizziness 